\title{
KINERJA KEUANGAN BANK MILIK PEMERINTAH INDONESIA \\ (Studi Kasus : BNI, BRI, BTN, Bank Mandiri)
}

\author{
Ahmad Soleh, Yun Fitriano \\ Program Studi Akuntansi Fakultas Ekonomi Universitas Dehasen Bengkulu \\ ahmadsolehse81@yahoo.co.id
}

\begin{abstract}
ABSTRAK
Ahmad Soleh, Yun Fitriano; Penelitian ini bertujuan untuk menganalisis perbandingan kinerja keuangan bank milik pemerintah dan memberikan bukti empiris pengaruh LDR, CAR, dan NPL terhadap ROA. Analisis ini menggunakan variabel independen likuiditas dan solvabilitas. Variabel independen difokuskan pada CAR, LDR, NPL, sedangkan variabel dependennya adalah profitabilitas yang difokuskan pada ROA. Data yang digunakan adalah data sekunder yang berasal dari laporan keuangan tahunan BNI, BRI, BTN, Bank Mandiri yang terdaftar di Bursa Efek Indonesia periode tahun 2008 sampai tahun 2015. Metode pengujian data menggunakan, uji asumsi klasik, regresi linear berganda, koefisien determinasi $\left(\mathrm{R}^{2}\right)$, dengan pengujian hipotesis uji t dan uji F. Hasil penelitian menunjukkan bahwa persamaan regresi linear berganda $\mathrm{Y}=1,145+0,023 \mathrm{X}_{1}+0,004 \mathrm{X}_{2}-0,281 \mathrm{X}_{3}$. Uji secara parsial (uji $\mathrm{t}$ ) menunjukkan rasio LDR bank milik pemerintah berpengaruh positif dan signifikan terhadap ROA dengan nilai $t_{\text {hitung }} 3,108>$ $t_{\text {tabel }}$ 1,693 dengan tingkat signifikan 0,0046 atau 0,46\%. Rasio CAR berpengaruh positif dan tidak signifikan terhadap ROA dengan nilai thitung 0,126 < t tabel 1,693 dengan tingkat signifikan 0,9004 atau 90,4\%. Rasio NPL berpengaruh negatif dan signifikan terhadap ROA dengan nilai thitung $-4,594<t_{\text {tabel }} 1,693$ dengan tingkat signifikan 0,0001 atau 0,01\%. Uji secara simultan (uji F) menunjukkan rasio LDR, CAR, dan NPL berpengaruh positif dan signifikan terhadap ROA dengan nilai Fhitung 26,414 > tabel 2,93 dengan tingkat signifikan 0,000 atau 0,0\%. Hasil pengujian koefisien determinasi $\left(\mathrm{R}^{2}\right)$ menunjukkan hasil bahwa variabel independen LDR, CAR, dan NPL dapat menjelaskan pengaruhnya terhada variabel dependen ROA, yaitu sebesar 0,863 atau 86,3\% sedangkan 13,7\% dipengaruhi oleh variabel lain yang tidak diteliti.
\end{abstract}

\section{ABSTRACT}

Ahmad Soleh, Yun Fitriano; This study aims to analyze the comparison of the financial performance of state-owned banks and provide empirical evidence of the effect of LDR, CAR, and NPL on ROA. This analysis uses an independent variable of liquidity and solvency. The independent variable is focused on CAR, LDR, $N P L$, while the dependent variable is profitability focused on ROA. The data used are secondary data derived from the annual financial statements of BNI, BRI, BTN, Bank Mandiri listed on the Indonesia Stock Exchange in the period 2008 to 2015. The method of testing data uses, classic assumption test, multiple linear regression, coefficient of determination (R2), by testing the hypothesis $t$ test and $F$ test. The results showed that the multiple linear regression equation $Y=1.145+0.023 X_{1}+0.004 X_{2}-0.281 X_{3}$. Partial test ( $t$ test) shows that the LDR ratio of government-owned banks has a positive and significant effect on ROA with a $t$ count of $3.108>t$ table 1.693 with a significant level of 0.0046 or $0.46 \%$. CAR ratio has a positive effect and is not significant for ROA with a t count of $0.126<t$ table 1.693 with a significant level of 0.9004 or $90.4 \%$. The NPL ratio has a negative and not significant effect on ROA with a tcount of $-4.594<t$ table 1.693 with a significant level of 0.0001 or $0.01 \%$. Simultaneous testing (F test) shows the ratio of LDR, CAR, and NPL has a positive and significant effect on ROA with a calculated $F$ value of $26.414>t$ table 2.93 with a significant level of 0.000 or $0.0 \%$. The results of testing the coefficient of determination $\left(R^{2}\right)$ shows that the independent variables LDR, CAR, and NPL can explain the effect on the dependent variable ROA, which is equal to 0.863 or $86.3 \%$ while $13.7 \%$ is influenced by other variables not examined.

Key Words: Liquidity, Solvability, Profitability, Government Bank

\section{LATAR BELAKANG}

Perbankan merupakan lembaga keuangan yang sangat penting peranannya dalam kegiatan ekonomi, melalui kegiatan perkreditan dan layanan jasa yang diberikan, bank dapat melayani berbagai kebutuhan sektor ekonomi dan perdagangan. Sehingga dapat dikatakan bahwa bank merupakan inti dari sistem keuangan suatu negara. Kinerja bank menjadi pertimbangan yang sangat penting bagi pihak-pihak yang berkepentingan pada bank. Pihak-pihak yang berkepentingan tersebut antara lain adalah investor, kreditur, pemerintah, karyawan serta masyarakat yang berkepentingan lainnya. Penilaian kinerja dapat diartikan sebagai penilaian prestasi yang dapat dicapai. Kinerja keuangan bank dapat dilihat dari laporan 
keuangan yang secara teratur di publikasikan. Laporan keuangan bank menunjukkan kondisi keuangan bank secara keseluruhan (Kasmir, 2012:280).

Laporan keuangan CSI yang berupa angka-angka yang merupakan rekaman dari transaksi yang terjadi. Untuk mengetahui informasi yang terdapat di dalam laporan keuangan dibutuhkan sebuah alat analisis. Alat analisis yang biasa digunakan adalah analisis laporan keuangan yang berupa rasiorasio laporan keuangan. Rasio keuangan tersebut dapat menggambarkan kinerja suatu bank serta bagaimana prospek bank tersebut di masa yang akan datang. Likuiditas merupakan kemampuan suatu bank untuk memenuhi kewajiban jangka pendek. Suatu bank dianggap likuid apabila mempunyai kesanggupan untuk membayar penarikan giro, tabungan, deposito berjangka, pinjaman bank yang segera jatuh tempo, pemenuhan permintaan kredit tanpa adanya suatu penundaan (Pandia, 2012:113). Rasio solvabilitas merupakan rasio yang digunakan untuk mengukur kemampuan bank dalam memenuhi kewajiban jangka panjangnya atau kemampuan bank untuk memenuhi kewajiban-kewajibannya jika terjadi liquidasi bank (Hery, 2016:161). Sedangkan rasio profitabilitas adalah rasio yang digunakan untuk mengukur tingkat efisiensi usaha dan profitabilitas bank yang bersangkutan (Hery, 2016:191).

Melihat kinerja perusahaan BUMN akhir-akhir ini menjadi sorotan masyarakat banyak dikarenakan ada beberapa perusahaan BUMN yang merugi, maka ada baiknya untuk melihat lebih dalam bagaimana kinerja perusahaan BUMN dari sektor perbankan. Bank yang menjadi objek dalam penelitian ini adalah bank milik pemerintah yang terdiri dari Bank Rakyat Indonesia (BRI), Bank Tabungan Negara (BTN), Bank Negara Indonesia (BNI), dan Bank Mandiri. Pengukuran kinerja bank milik pemerintah dalam penelitian ini menggunakan analisis rasio yang ditinjau dari sisi Likuiditas, Solvabilitas, dan Profitabilitas. Analisis perbandingan kinerja keuangan juga dilakukan dengan memberikan bukti empiris pengaruh LDR, CAR, dan NPL terhadap ROA. Menggunakan variabel independen likuiditas dan solvabilitas. Variabel independen difokuskan pada CAR, LDR, NPL, sedangkan variabel dependennya adalah profitabilitas yang difokuskan pada ROA. Data yang digunakan adalah data sekunder yang berasal dari laporan keuangan tahunan BNI, BRI, BTN, Bank Mandiri yang terdaftar di Bursa Efek Indonesia periode tahun 2008 sampai tahun 2015.

\section{LANDASAN TEORI}

Bank

Bank secara sederhana dapat diartikan sebagai lembaga keuangan yang kegiatan utamanya adalah menghimpun dana dari masyarakat berupa tabungan, deposito, serta memberikan jasa-jasa lainnya. Menurut Undang-Undang No. 10 tahun 1998 yang dimaksud dengan bank adalah sebagai badan usaha yang menghimpun dana dari masyarakat dalam bentuk simpanan dan menyalurkan kepada masayarakat dalam bentuk kredit dalam rangka meningkatkan taraf hidup rakyat banyak. Taswan (2010:6) menyatakan bahwa bank adalah sebuah lembaga atau perusahaan yang aktivitasnya menghimpun dana berupa giro, deposito, tabungan dan simpanan yang lain dari pihak-pihak yang kelebihan dana, kemudian menempatkan kembali kepada masyarakat yang kekurangan dana melalui penjualan jasa keuangan yang pada giliran nya dapat meningkatkan kesejahteraan rakyat banyak. Pernyataan dari Hasibuan (2006:2) bank adalah lembaga keuangan berarti bank adalah badan usaha yang kekayaan nya terutama dalam bentuk asset keuangan (finacial asset) serta bermotifkan profit dan juga sosial, jadi bukan hanya mencari keutungan saja. Bank adalah suatu lembaga keuangan yang tugas utamanya adalah sebagai lembaga perantara keuangan, yang menyalurkan dana kepada pihak yang membutuhkan dana atau kekurangan dana pada waktu yang ditentukan (Dendawijaya, 2008:14). Menurut Kasmir (2009:25) bank adalah tempat penukarkan uang atau menerima segala macam bentuk pembayaran. Berdasarkan penjelasan beberapa ahli tersebut, dapat disimpulkan bahwa usaha perbankan meliputi tiga kegiatan utama, yaitu (1) Menghimpun dana (funding); (2) Menyalurkan dana (lending); dan (3) Memberikan jasa bank lainnya (service). Kegiatan menghimpun dan menyalurkan dana merupakan kegiatan pokok perbankan, sedangkan kegiatan memberikan jasa-jasa bank lainnya hanyalah merupakan pendukung dari kedua kegiatan diatas.

\section{Jenis-jenis Bank}

Jenis-jenis bank di Indonesia dapat ditinjau dari beberapa segi antara lain dilihat dari segi fungsinya, dilihat dari segi kepemilikannya, dan dapat dilihat dari segi statusnya (Kasmir, 2010:19). Dari segi fungsinya, berdasarkan Undang-undang No. 10 tahun 1998 jenis perbankan berdasarkan fungsinya terdiri dari (a) Bank Umum adalah bank yang melaksanakan kegiatan usaha secara konvensional dan atau berdasarkan prinsip syariah yang dalam kegiatannya memberikan dalam lalu lintas pembayaran. Sifat jasa yang diberikan adalah umum, dalam arti dapat memberikan seluruh jasa perbankan yang ada; (b) Bank Perkreditan Rakyat (BPR) adalah bank yang melaksanakan kegiatan usaha secara konvensional atau berdasarkan prinsip syariah. Dalam kegiatannya BPR tidak memberikan jasa dalam lalu lintas 
pembayaran. Artinya jasa-jasa perbankan yang ditawarkan BPR jauh lebih sempit jika dibandingkan dengan kegiatan atau jasa bank umum. Dari segi kepemilikannya, kepemilikan bank dapat dilihat dari akte pendirian dan penguasaan saham yang dimiliki bank yang bersangkutan, jenis bank dilihat dari segi kepemilikannya dapat dibagi menjadi (a) Bank Milik Pemerintah merupakan bank yang akte pendirian maupun modal bank sepenuhnya dimilki oleh pemerintah Indonesia, sehingga seluruh keuntungan bank dimiliki oleh pemerintah pula; (b) Bank Milik Swasta Nasional merupakan bank yang seluruh atau sebagian besar sahamnya dimiliki oleh swasta nasional. Kemudian akte pendiriannyapun didirikan oleh swasta, begitupula dengan pembagian keuntungannya untuk keuntungan swasta pula; (c) Bank Milik Koperasi merupakan bank yang kepemilikan saham-sahamnya dimiliki oleh perusahaan yang berbadan hukum koperasi; (d) Bank Milik Asing, Jenis bank ini merupakan cabang dari bank yang ada diluar negeri, baik miliki swasta asing atau pemerintah asing; (e) Bank Milik Campuran merupakan jenis bank yang kepemilikan sahamnya dimiliki oleh pihak asing dan swasta nasional. Kepemilikan sahamnya secara mayoritas dipegang oleh warga negara Indonesia.

\section{Laporan Keuangan Bank}

Laporan keuangan bank menunjukkan kondisi keuangan bank secara keseluruhan, laporan keuangan juga menujukkan kinerja manajemen bank selama satu periode (Kasmir, 2012:280). Sedangkan Darminto (2011:5) menyatakan bahwa laporan keuangan adalah laporan yang disusun dengan tujuan untuk menyediakan informasi yang menyangkut posisi keuangan, kinerja, dan dan posisi keuangan suatu perusahaan yang bermanfaat bagi sejumlah besar pemakai dalam pengambilan keputusan ekonomi.

Dalam rangka transparansi kondisi keuangan dan kinerja bank, bank wajib menyusun, mengumumkan, dan menyampaikan laporan publikasi terdiri dari (OJK, 2016:88) :

1. Laporan publikasi bulanan

Laporan publikasi bulanan berupa laporan keuangan yang disusun berdasarkan laporan bulanan bank yang disampaikan kepada Bank Indonesia dan di publikasikan bulanan yang meliputi neraca dan laporan laba rugi.

2. Laporan publikasi triwulanan

Laporan publikasi triwulanan adalah laporan yang disusun berdasarkan standar akuntansi keuangan yang berlaku dan di publikasikan setiap triwulan, laporan tersebut meliputi : neraca, laporan laba rugi, laporan komitmen dan kontinjensi, transaksi valuta asing dan derivative, kualitas aktiva produktif dan informasi lainnya, perhitungan kewajiban penyedia modal minimum dan perhitungan rasio keuangan.

3. Laporan publikasi tahunan

Laporan publikasi tahunan adalah laporan keuangan akhir tahun bank yang disusun berdasarkan standar akuntansi keuangan yang berlaku dan wajib di audit oleh akuntan publik, laporan tersebut terdiri dari : neraca, laporan laba rugi, laporan perubahan ekuitas laporan arus kas dan catatan atas laporan keuangan, termasuk informasi tentang komitmen dan kontinjensi.

\section{Kinerja Keuangan Bank}

Kinerja keuangan adalah suatu kegiatan yang dilakukan oleh suatu perusahaan dan menggunakan modal secara efisien dan efektif guna tercapainya tujuan perusahaan. Analisis kinerja keuangan bank dilakukan untuk melihat sejauh mana suatu perusahaan telah melaksanakan dengan menggunakan aturan-aturan pelaksanaan keuangan secara baik dan benar (Fahmi, 2012:2). Kinerja keuangan bank adalah sebagai hasil fungsi pekerjaan seseorang yang dipengaruhi oleh berbagai faktor untuk mencapai tujuan organisasi dalam waktu periode tertentu (Tika, 2006:121).

Kinerja keuangan merupakan suatu pencapaian prestasi pada satu periode yang menggambarkan kondisi kesehatan keuangan perusahaan dengan indikator kecukupan modal, likuiditas, dan profitabilitas. Kinerja keuangan bank dapat di analisis dengan menggunakan laporan keuangan. Secara umum ada lima tahap dalam menganalisis kinerja keuangan (Fahmi, 2014:3), yaitu (1) Melakukan review terhadap data laporan keuangan; (2) Melakukan perhitungan; (3) Melakukan perbandingan terhadap hasil hitungan yang telah diperoleh; (4) Melakukan penafsiran terhadap berbagai permasalahan yang ditemukan; dan (5) Mencari dan memberikan pemecahan masalah terhadap berbagai permasalahan yang ditemukan.

\section{Analisis Rasio Keuangan Bank}

Dalam penelitian ini, pengukuran perbandingan kinerja keuangan bank milik pemerintah di lihat dari rasio likuiditas, solvabilitas, dan profitabilitas

1. Rasio Likuiditas

Rasio likuiditas mengukur kemampuan bank dalam memenuhi kemmapuan jangka pendeknya pada saat ditagih. Suatu bank dikatakan likuid apabila dapat membayar hutang-hutang terutama simpanan tabungan, giro, dan deposito pada saat ditagih dan dapat memenuhi permintaan kredit yang diajukan 
oleh para nasabah (Kasmir, 2008:41). Penilaian likuiditas bank dilakukan melalui penilaian Loan to Deposite Ratio (LDR). Loan to Deposite Ratio adalah rasio antar besarnya seluruh volume kredit yang salurkan kepada nasabah dengan jumlah penerimaan dana yang dihimpun dari pihak ketiga. Semakin tinggi rasio ini menunjukkan semakin baik kinerja bank dalam mengelolah dana pihak ketiga berupa tabungan, giro, dan deposito. Ambang batas normal rasio LDR adalah 110\%, rasio LDR dapat dihitung dengan menggunakan rumus :

$$
\mathrm{LDR}=\frac{\text { Total Kredit Yang Diberikan }}{\text { Total Dana Pihak Ketiga }} \quad \mathrm{x} 100 \%
$$

2. Rasio Solvabilitas

Rasio solvabilitas merupakan gambaran kemampuan bank dalam memenuhi dan menjaga kemampuannya untuk selalu mampu memenuhi kewajibannya dalam membayar utang secara tepat waktu (Fahmi, 2014:87). Penilaian solvabilitas bank dilakukan melalui penilaian rasio Capital Adequacy Ratio (CAR) dan Non Performing Loan (NPL).

a. Capital Adequacy Ratio (CAR)

Capital Adequacy Ratio (CAR) adalah rasio permodalan suatu bank yang menunjukkan kemampuan suatu bank dalam menyediakan dana untuk keperluan pengembangan usaha serta menampung kemungkinan resiko kerugian yang diakibatkan dalam operasional bank. CAR adalah rasio kebutuhan modal minimum yang dihitung berdasarkan Aset Tertimbang Menurut Resiko (ATMR), berdasarkan peraturan Bank Indonesia rasio CAR minimum bank umum adalah sebesar 8\%. Semakin besar CAR menujukkan semakin baik kinerja bank tersebut, rasio CAR dapat dihitung dengan rumus :

$$
\mathrm{CAR}=\frac{\text { Modal Bank }}{\text { Total ATMR }} \quad \mathrm{x} 100 \%
$$

b. Non Performing Loan (NPL)

Non Performing Loan (NPL) adalah rasio yang digunakan untuk mencerminakan resiko kredit yang ditanggung oleh bank, semakin besar rasio NPL menunjukkan semakin besar beban yang ditanggung oleh bank yang dapat menyebabkan bank menjadi bangkrut akibat kredit bermasalah. Bank Indonesia menetapkan batas maksimum rasio NPL adalah sebesar 5\%. Jika rasio NPL melebihi 5\% maka bank tersebut sedang dalam masalah dalam pengelolaan kredit. Rumus untuk menghitung rasio ini :

$$
\text { NPL }=\frac{\text { Kredit Bermasalah }}{\text { Total Kredit }} \times 100 \%
$$

3. Rasio profitabilitas

Rasio profitabilitas merupakan rasio yang digunakan untuk mengukur kemampuan bank secara keseluruhan yang ditujukan oleh besar kecilnya keuntungan yang diperoleh dalam hubungan dengan penjualan dan investasi (Fahmi, 2014:68). Penilian rasio profitabilitas bank dilakukan melalui penilaian rasio Return On Asset (ROA). Return On Asset (ROA) merupakan rasio yang digunakan untuk mengukur kemampuan bank dalam mendapatkan laba. ROA juga digunakan untuk melihat sejauh mana investasi yang telah ditanamkan mampu memberikan pengembalian keuntungan sesuai dengan yang diharapkan berdasarkan asset yang dimiliki. Semkain besar rasio ROA bank menunjukkan semakin besar pula tingkat keuntungan yang dicapai bank tersebut dan semakin baik pula posisi bank dalam pengunaan asset. ROA dapat dihitung dengan rumus :

$$
\mathrm{ROA}=\frac{\text { Laba Bersih Sebelum Pajak }}{\text { Total Aktiva }} \times 100 \%
$$

\section{KERANGKA ANALISIS}

Agar memudahkan pemahaman dalam penelitian ini, maka perlu dibuat kerangka analisis seperti ditunjukkan pada gambar 1. Gambar 1 menjelaskan alur penelitian yakni mengkaji laporan keuangan yang terdiri atas neraca, laporan laba rugi, dan laporan kewajiban penyedia modal minimum. Selanjutnya dari laporan keuangan tersebut, dianalisis likuiditas (LDR) dan solvabilitas (CAR dan NPL). Analisis dilanjutkan dengan melihat pengaruh variabel independen (likuiditas dan solvabilitas) difokuskan pada LDR, CAR, dan NPL terhadap variabel dependen yakni profitabilitas yang difokuskan pada ROA. Selanjutnya akan diperoleh persamaan regresi linear berganda, koefisien determinasi $\left(R^{2}\right)$, serta pengujian hipotesis secara parsial (uji t) dan pengujian hipotesis simultan (uji F). 


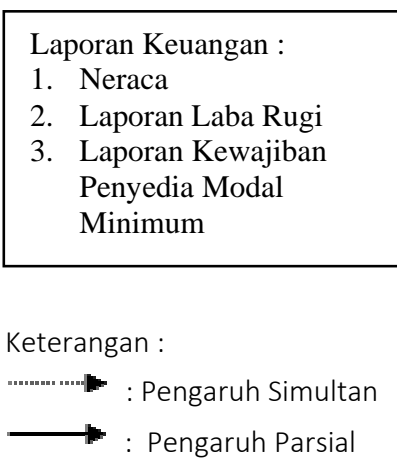

Laporan Keuangan :

1. Neraca

Penyedia Modal

Minimum

Keterangan :
: Pengaruh Simultan
: Pengaruh Parsial

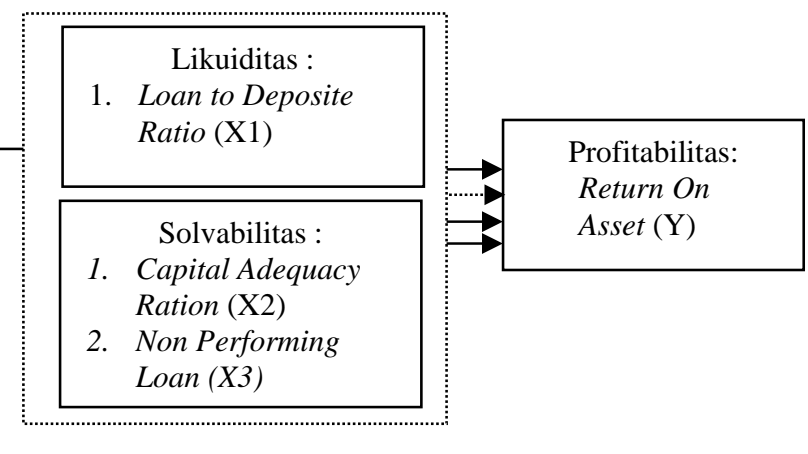

Gambar 1. Kerangka Analisis

\section{METODOLOGI}

\section{Jenis dan Metode Pengumpulan Data}

Penelitian ini termasuk penelitian kuantitatif dengan menggunakan data sekunder. Penelitian kuantitatif adalah suatu proses menemukan pengetahuan yang menggunakan data berupa angka sebagai alat menganalisis keterangan mengenai apa yang ingin diketahui (Kasiram, 2008:149). Data sekunder adalah informasi tangan kedua yang telah dikumpulkan oleh beberapa orang (organisasi) untuk tujuan tertentu dan tersedia untuk berbagai penelitian (Riadi, 2016:48). Dalam hal ini data sekunder yang di maksud adalah dat-data laporan keuangan bank milik pemerintah periode tahun 2008-2015 (BRI, BTN, BNI, Bank Mandiri). Data-data tersebut dikumpulkan melalui website resmi Bursa Efek Indonesia yang di akses melalui www.idx.co.id.

\section{Metode Analisis}

Metode analisis data menggunakan metode statistik. Penelitian ini menggunakan analisis regresi linear berganda dengan sistem data panel, tetapi sebelum analisis regresi linear dilakukan data di uji terlebih dahulu dengan uji asumsi klasik untuk memastikan model regresi yang digunakan tidak terdapat masalah normalitas, multikolinearitas, heteroskedastisitas. Program yang digunakan untuk melakukan analisis data adalah Eviews Versi 9.

\section{Analisis Regresi Linier Berganda}

Analisis regresi linear berganda digunakan untuk menguji pengaruh lebih dari satu variabel independen terhadap variabel dependen (Wijaya, 2011:98). Dalam penelitian ini sebagai variabel independen dari aspek likuiditas adalah Loan to Desposite Ratio (LDR), dari aspek solvabilitas adalah Capital Adequacy Ratio (CAR) dan Non Performing Loan (NPL). Sedangkan variabel dependen dari aspek profitabilitas adalah Return On Asset (ROA). Bentuk persamaan regresi linear berganda empat variabel (Riadi, 2016:187) adalah :

$$
\hat{Y}=a_{0}+b_{1} X_{1}+b_{2} X_{2}+b_{3} X_{3}
$$

\footnotetext{
Keterangan:

$\hat{\mathrm{Y}} \quad=\quad$ Return On Asset (ROA)

$\mathrm{A} \quad=\quad$ Koefisien regresi linear berganda

$\mathrm{X}_{1}, \mathrm{X}_{2}, \mathrm{X}_{3} \quad=\quad$ Loan to Deposite Ratio (LDR), Capital Adequacy Ratio (CAR), Non Performing Loan (NPL)

$\mathrm{b}_{1} \quad=\quad$ Besarnya kenaikan/penurunan $\mathrm{Y}$ dalam satuan, jika $\mathrm{X}_{1}$ naik satu satuan sedangkan $\mathrm{X}_{2}$ dan $\mathrm{X}_{3}$ tetap.

$\mathrm{b}_{2}=$ Besarnya kenaikan/penurunan $\mathrm{Y}$ dalam satuan, jika $\mathrm{X}_{2}$ naik satu satuan sedangkan $\mathrm{X}_{1}$ dan $\mathrm{X}_{3}$ tetap.

$\mathrm{b}_{3} \quad=\quad$ Besarnya kenaikan/penurunan $\mathrm{Y}$ dalam satuan, jika $\mathrm{X}_{3}$ naik satu satuan sedangkan $\mathrm{X}_{1}$ dan $\mathrm{X}_{2}$ tetap.

+ atau - = Tanda yang menunjukan arah hubungan (positif atau negatif) antara $\mathrm{Y}$ dan $\mathrm{X}_{1}, \mathrm{X}_{2}$ atau $\mathrm{X}_{3}$.
} 


\section{Uji Hipotesis}

Hipotesis yang di uji dalam penelitian ini berkaitan dengan ada atau tidaknya pengaruh dari variabel independen Loan to Deposite Ratio (LDR), Capital Adequacy Ratio (CAR), Non Performing Loan (NPL) terhadap variabel dependen Return On Asset (ROA) baik secara parsial maupun secara simultan.

1. Uji t (Parsial)

Uji t digunakan apakah variabel independen secara parsial berpengaruh terhadap variabel dependen. Langkah dalam mengguji t adalah sebagai berikut :

a. Merumuskan hipotesis

$\mathrm{H}_{0}$ : $\quad$ artinya tidak ada pengaruh yang signifikan antara variabel independen terhadap variabel dependen. Loan to Deposite Ratio (LDR), Capital Adequacy Ratio (CAR), Non Performing Loan (NPL) secara parsial tidak berpengaruh terhadap Return On Asset (ROA).

$\mathrm{H}_{1}$ : artinya ada pengaruh yang signifikan antara variabel independen terhadap variabel dependen. Loan to Deposite Ratio (LDR), Capital Adequacy Ratio (CAR), Non Performing Loan (NPL) secara parsial berpengaruh terhadap Return On Asset (ROA).

b. Menetapkan tingkat signifikan yang digunakan yaitu 0,05

c. Menetapkan keputusan

(1) Jika probabilitas (sig $\mathrm{t})>\alpha(0,05)$ maka $\mathrm{H}_{0}$ diterima dan $\mathrm{H}_{1}$ ditolak, artinya tidak ada pengaruh yang signifikan secara parsial dari variabel independen terhadap variabel dependen.

(2) Jika probabilitas (sig $\mathrm{t})<\alpha(0,05)$ maka $\mathrm{H}_{0}$ di tolak dan $\mathrm{H}_{1}$ diterima, artinya ada pengaruh yang signifikan secara pasrsial dari variabel independen terhadap variabel dependen.

2. Uji F (Simultan)

Uji F digunakan untuk menguji apakah variabel-variabel independen secara bersama-sama signifikan berpengaruh terhadap variabel dependen. Langkah dalam uji F sebagai berikut :

a. Menentukan hipotesis

$\mathrm{H}_{0}$ : artinya variabel independen secara bersama-sama tidak berpengaruh signifikan terhadap variabel dependen. Secara simultan Loan to Deposite Ratio (LDR), Capital Adequacy Ratio (CAR), Non Performing Loan (NPL) tidak mempunyai pengaruh yang signifikan terhadap Return On Asset (ROA).

$\mathrm{H}_{1}$ : artinya variabel independen secara bersama-sama berpengaruh signifikan terhadap variabel dependen. Secara simultan Loan to Deposite Ratio (LDR), Capital Adequacy Ratio (CAR), Non Performing Loan (NPL) mempunyai pengaruh yang signifikan terhadap Return On Asset (ROA).

b. Menetapkan tingkat signifikan yang digunakan yaitu 0,05.

c. Pengambilan keputusan

(1) Jika probabilitas (sig F) $>\alpha(0,05)$ maka $\mathrm{H}_{0}$ diterima dan $\mathrm{H}_{1}$ ditolak, artinya tidak ada pengaruh yang signifikan secara simultan dari variabel independen terhadap variabel dependen.

(2) Jika probabilitas ( $\operatorname{sig} \mathrm{F})<\alpha(0,05)$ maka $\mathrm{H}_{0}$ di tolak dan $\mathrm{H}_{1}$ diterima, artinya ada pengaruh yang signifikan secara simultan dari variabel independen terhadap variabel dependen.

3. Koefisien Determinasi $\left(\mathrm{R}^{2}\right)$

Adalah untuk mengukur seberapa jauh kemampuan variabel independen dalam menjelaskan variabel dependen

\section{HASIL PENELITIAN DAN PEMBAHASAN}

\section{Perbandingan Kinerja Keuangan dari sisi LDR}

Rasio LDR merupakan komposisi dari kredit yang diberikan dan total dana pihak ketiga yang berhasil dihimpun oleh bank. Pengelolaan dana pihak ketiga berupa tabungan, deposito, dan giro dapat dimanfaatkan untuk memenuhi kebutuhan debitur berupa pinjaman kredit. Kredit yang disalurkan kepada debitur merupakan salah satu faktor yang dapat memberikan keuntungan bagi bank. Penilaian kinerja keuangan bank milik pemerintah dari sisi rasio LDR dapat ditampilkan dalam bentuk grafik berikut: 


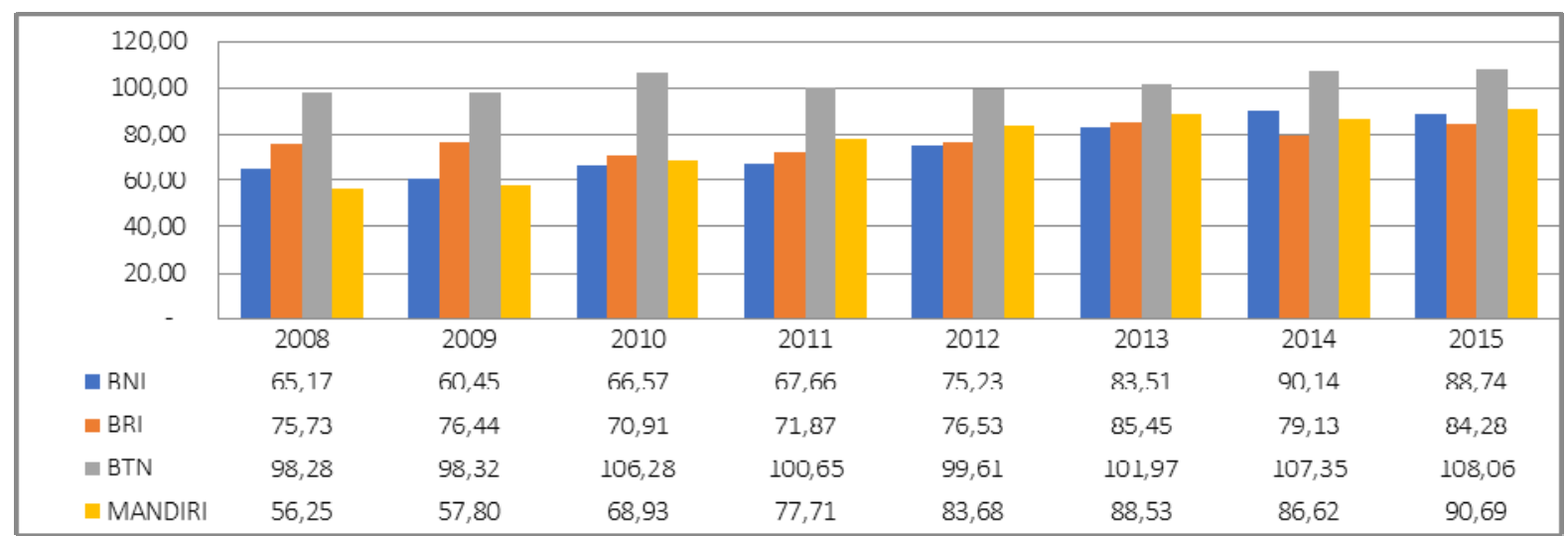

Sumber : hasil penelitian (data diolah), 2018.

Gambar 2. Perbandingan Kinerja Keuangan dari sisi LDR Bank Milik Pemerintah (BNI, BRI, BTN, Bank Mandiri) Tahun 2008-2015

Berdasar gambar 2 di atas, rata-rata posisi rasio LDR dari tahun 2008 sampai tahun 2015, maka dengan berpedoman pada peraturan Bank Indonesia tentang sistem penilaian tingkat kesehatan bank adalah sebagai berikut :

Tabel 1. Standar Ukuran Rasio LDR

\begin{tabular}{|c|c|c|c|c|c|}
\hline \multirow{2}{*}{ Rasio Keuangan } & \multicolumn{5}{|c|}{ Standar Bank Indonesia } \\
\cline { 2 - 6 } & Sangat Baik & Baik & Cukup Baik & Kurang Baik & Tidak Baik \\
\hline LDR & $<75 \%$ & $<85 \%$ & $<100 \%$ & $<120 \%$ & $>120 \%$ \\
\hline
\end{tabular}

1. PT. Bank Tabungan Negara, Tbk memiliki rata-rata rasio LDR sebesar $102,57 \%$, jika dilihat dari kondisi rata-rata rasio LDR, hal ini sebenarnya menunjukkan kinerja keuangan dari sisi rasio LDR sudah dalam kondisi yang kurang baik.

2. PT. Bank Rakyat Indonesia, Tbk memiliki rata-rata rasio LDR sebesar $77,54 \%$, kinerja keuangan dari sisi rasio LDR PT. Bank Rakyat Indonesia, Tbk dapat dikatakan dalam kondisi yang baik.

3. PT. Bank Mandiri, Tbk memiliki rata-rata rasio LDR sebesar $76,28 \%$, kinerja keuangan dari sisi rasio LDR PT. Bank Mandiri, Tbk dapat dikatakan dalam kondisi yang baik.

4. PT. Bank Negara Indonesia, Tbk memiliki nilai rata-rata sebesar $74,68 \%$, kinerja keuangan dari sisi rasio LDR PT. Bank Mandiri, Tbk dapat dikatakan dalam kondisi yang sangat baik.

Berdasarkan hasil penilaian rasio LDR bank milik pemerintah dari tahun 2008 sampai tahun 2015, PT. Bank Rakyat Indonesia, Tbk, PT. Bank Mandiri, Tbk, PT. Bank Negara Indonesia, Tbk masing-masing menempati peringkat 1, 2, dan 3 dengan predikat rasio LDR yang baik, sedangkan PT. Bank Tabungan Negara, Tbk pada tahun 2008 sampai tahun 2015 memiliki predikat rasio LDR dalam kondisi yang kurang baik. Tingkat rasio LDR PT. Bank Tabungan Negara, Tbk berada pada kondisi yang kurang baik dikarenakan kredit perumahan rakyat (KPR) rata-rata menggunakan jasa PT. Bank Tabungan Negara, Tbk.

\section{Perbandingan Kinerja Keuangan dari sisi CAR}

Selain penilaian dari sisi LDR, kinerja keuangan bank juga dapat dinilai dari sisi rasio CAR. CAR merupakan rasio permodalan bank yang komposisinya terdiri dari modal bank dan asset tertimbang menurut risiko. Bank yang memiliki struktur modal yang baik tentu akan dapat beroperasional dengan baik pula. Faktor permodalan dapat juga mempengaruhi tingkat perolehan laba. Berdasarkan hasil penelitian mengenai kinerja keuangan bank milik pemerintah (BNI, BRI, BTN, Mandiri), maka penilaian kinerja keuangan bank milik pemerintah dari sisi rasio CAR dapat ditampilkan dalam bentuk grafik berikut : 


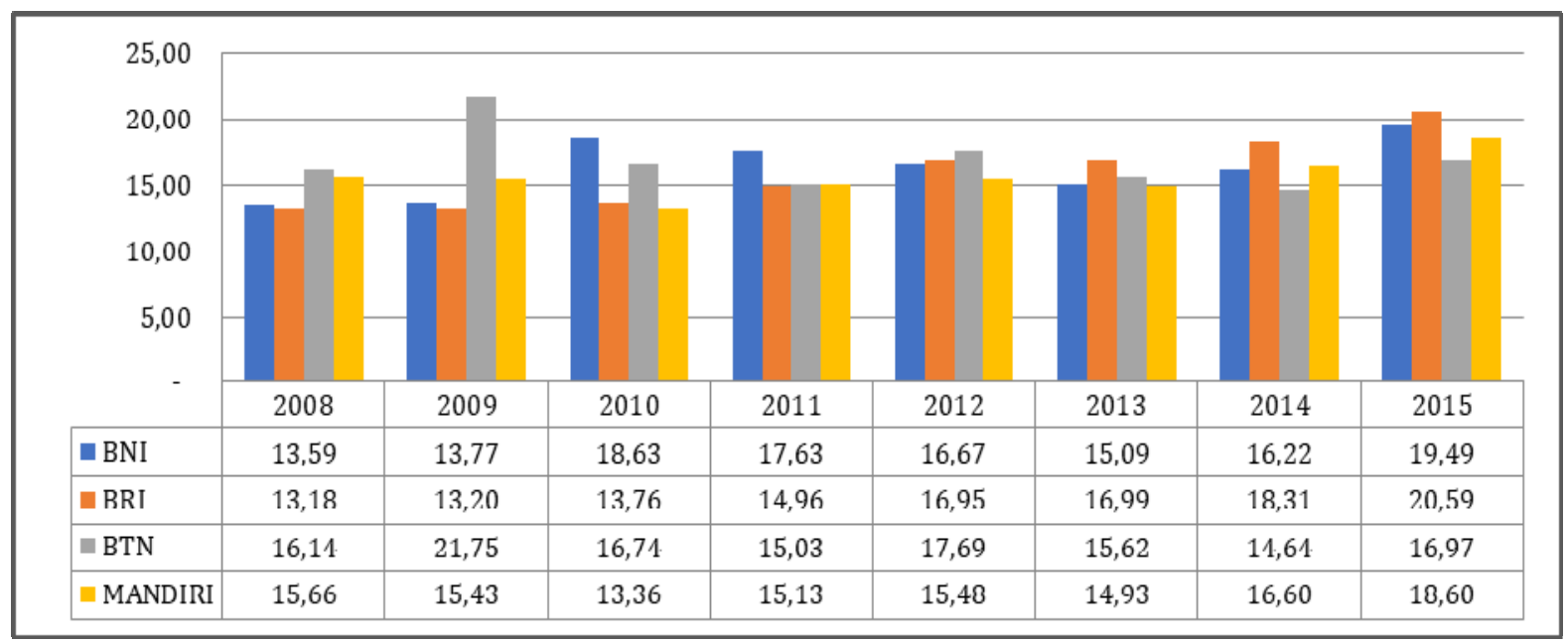

Sumber : hasil penelitian (data diolah), 2018.

Gambar 3. Perbandingan Kinerja Keuangan dari sisi CAR Bank Milik Pemerintah (BNI, BRI, BTN, Bank Mandiri) Tahun 2008-2015

Berdasar gambar 3 di atas, rata-rata posisi rasio CAR dari tahun 2008 sampai tahun 2015, dengan berpedoman pada peraturan Bank Indonesia tentang sistem penilaian tingkat kesehatan bank adalah sebagai berikut :

Tabel 2. Standar Ukuran Rasio CAR

\begin{tabular}{|c|c|c|c|c|c|}
\hline \multirow{2}{*}{ Rasio Keuangan } & \multicolumn{5}{|c|}{ Standar Bank Indonesia } \\
\cline { 2 - 6 } & Sangat Baik & Baik & Cukup Baik & Kurang Baik & Tidak Baik \\
\hline CAR & $>11 \%$ & $9,5 \% \leq 11 \%$ & $8 \% \leq 9,5 \%$ & $6,5 \% \leq 8 \%$ & $<6,5 \%$ \\
\hline
\end{tabular}

1. PT. Bank Tabungan Negara, Tbk memiliki nilai rata-rata rasio CAR sebesar $16,82 \%$, rasio kecukupan modal PT. Bank Tabungan Negara, Tbk dalam kondisi yang sangat baik.

2. PT. Bank Negara Indonesia, Tbk memiliki nilai rata-rata rasio CAR sebesar $16,39 \%$, rasio kecukupan modal PT. Bank Negara Indonesia, Tbk dalam kondisi yang sangat baik.

3. PT. Bank Rakyat Indonesia, Tbk memiliki nilai rata rasio CAR sebesar $15,99 \%$, rasio kecukupan modal PT. Rakyat Indonesia, Tbk dalam kondisi yang sangat baik.

4. PT. Bank Mandiri, Tbk memiliki nilai rata-rata rasio CAR sebesar 15,65\%, rasio kecukupan modal PT. Bank Mandiri, Tbk dalam kondisi yang sangat baik.

Berdasarkan penilaian kinerja keuangan dari sisi rasio CAR, bank milik pemerintah memenuhi standar kecukupan modal yang ditetapkan oleh Bank Indoensia, yaitu sebesar 8\% dan keempat bank milik pemerintah menempati posisi kecukupan modal dengan predikat sangat baik. Kecukupan modal ini seiring dengan terus berkembangnya bisnis perbankan yang menyebabkan manajemen perbankan terus berupaya memperkuat struktur modal nya untuk tetap dapat bersaing dalam memberikan kebutuhan keuangan kepada masyarakat.

\section{Perbandingan Kinerja Kinerja dari sisi NPL}

Non Performing Loan (NPL) merupakan komposisi dari kredit bermasalah (kurang lancar, diragukan, dan macet) dengan total kredit. NPL merupakan rasio kredit bermasalah, batas maksimum NPL yang ditetapkan oleh Bank Indonesia adalah sebesar 5\%, jika rasio NPL sudah di atas 5\% maka bank sudah dalam kondisi risiko kredit yang tinggi. NPL juga dapat berpengaruh terhadap laba perusahaan, karena perolehan laba perushaaan salah satunya dari jumlah kredit yang diberikan, dengan asumsi kredit tersebut tidak mengalami masalah dan bank dapat memperoleh pengembalian berupa pokok pinjaman beserta bunga. Oleh karena itu, penilaian NPL penting untuk dilakukan. Berdasarkan hasil penelitian mengenai kinerja keuangan bank milik pemerintah (BNI, BRI, BTN, Mandiri), maka penilaian kinerja keuangan bank milik pemerintah dari sisi rasio NPL dapat ditampilkan dalam bentuk grafik berikut : 


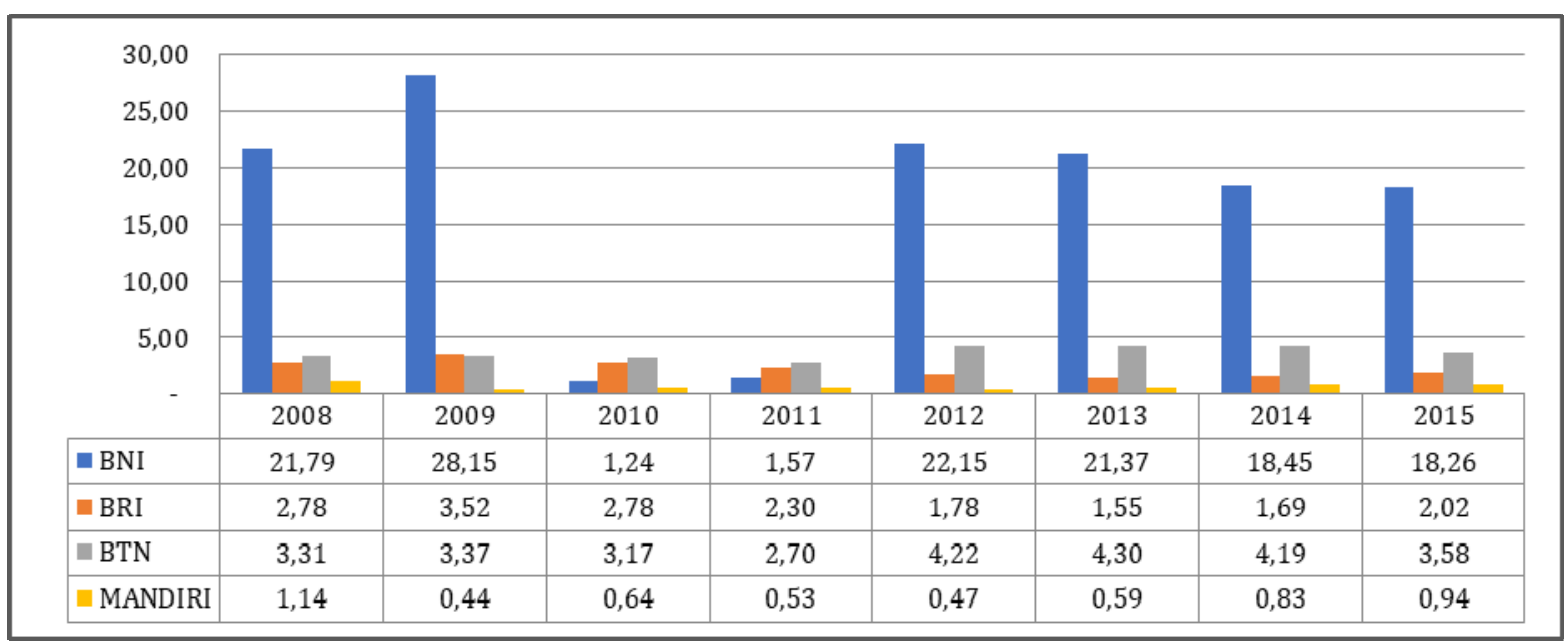

Sumber : hasil penelitian (data diolah), 2018.

Gambar 4. Perbandingan Kinerja Keuangan dari sisi NPL Bank Milik Pemerintah (BNI, BRI, BTN, Bank Mandiri) Tahun 2008-2015

Dari gambar 4 di atas, rata-rata posisi rasio NPL dari tahun 2008 sampai tahun 2015, dengan berpedoman pada peraturan Bank Indonesia tentang sistem penilaian tingkat kesehatan bank adalah sebagai berikut :

Tabel 3. Standar Ukuran Rasio NPL

\begin{tabular}{|c|c|c|c|c|c|}
\hline \multirow{2}{*}{ Rasio Keuangan } & \multicolumn{5}{|c|}{ Standar Bank Indonesia } \\
\cline { 2 - 6 } & Sangat Baik & Baik & Cukup Baik & Kurang Baik & Tidak Baik \\
\hline NPL & $<5 \%$ & $7 \% \leq 10 \%$ & $10 \% \leq 13 \%$ & $13 \% \leq 16 \%$ & $>16 \%$ \\
\hline
\end{tabular}

1. PT. Bank Mandiri, Tbk memiliki rata-rata NPL sebesar 0,70\%, kinerja manajemen PT. Bank Mandiri, Tbk dalam menekan angka kredit bermasalah terletak pada predikat sangat baik.

2. PT. Bank Negara Indonesia, Tbk memiliki rata-rata NPL sebesar $0,90 \%$, dengan berhasilnya manajemen PT. Bank Negara Indonesia, Tbk menekan angka rasio NPL berada pada posisi $<5 \%$, maka dapat menempatkan PT. Bank Negara Indonesia, Tbk berada pada posisi kedua dengan predikat NPL sangat baik.

3. PT. Bank Rakyat Indonesia, Tbk memiliki rata-rata NPL sebesar 2,30\%, kinerja manajemen PT. Bank Rakyat Indonesia, Tbk dari sisi pengelolaan kredit juga menempati predikat sangat baik.

4. PT. Bank Tabungan Negara, Tbk satu-satunya bank milik pemerintah yang memiliki rata-rata angka rasio NPL sebesar 3,60\%, namus kondisi ini masih dalam predikat yang sangat baik.

Berdasarkan penilaian kinerja keuangan dari sisi rasio NPL, bank milik pemerintah dapat mengelola kredit bermasalah dengan predikat sangat baik. Hal ini dapat menghindarkan bank dari risiko kebangkrutan akibat tingginya kredit bermasalah. Manajemen bank milik pemerintah dirasa mampu menekan angka kredit bermasalah yang ditetapkan oleh Bank Indonesia, yaitu dibawah 5\%. Kemampuan manajemen bank dalam menekan angka kredit bermasalah tentunya tidak lepas dari kondisi perekonomian yang cukup stabil, sehingga masyarakat dapat memenuhi kewajibannya tepat pada waktu yang telah ditetapkan.

\section{Perbandingan Kinerja Keuangan dari sisi ROA}

Return On Asset (ROA) merupakan komposisi antara laba sebelum pajak dengan total aktiva. Penilaian rasio ROA dapat digunakan untuk melihat tingkat pengembalian atau tingkat keuntungan yang diperoleh bank dari kegiatan operasionalnya. ROA yang tinggi dapat memberikan keuntungan tersendiri bagi kegiatan usaha bank. Berdasarkan hasil penelitian mengenai kinerja keuangan bank milik pemerintah (BNI, BRI, BTN, Mandiri), maka penilaian kinerja keuangan bank milik pemerintah dari sisi rasio ROA dapat ditampilkan dalam bentuk grafik berikut: 


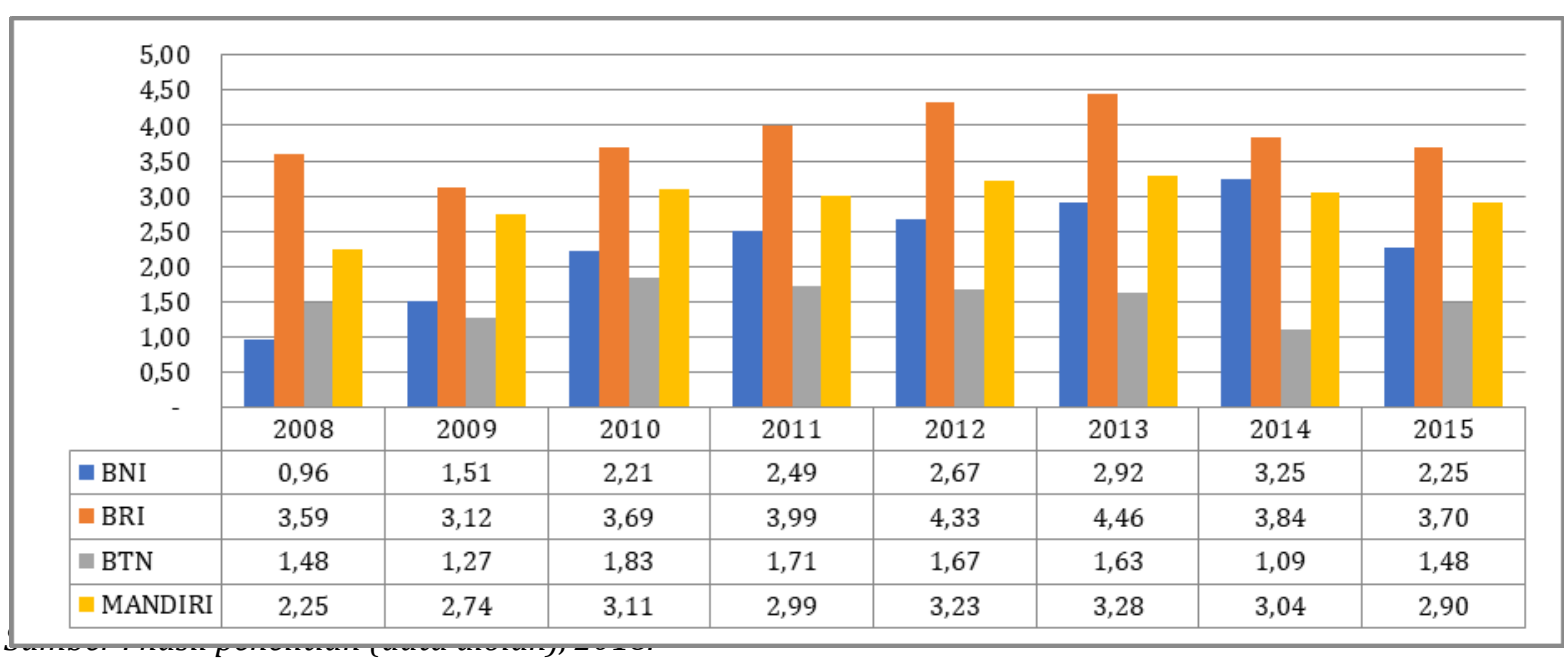

Gambar 5. Perbandingan Kinerja Keuangan dari sisi ROA Bank Milik Pemerintah (BNI, BRI, BTN, Bank Mandiri) Tahun 2008-2015

Dari gambar 5 di atas, rata-ratakan posisi rasio ROA dari tahun 2008 sampai tahun 2015, dengan berpedoman pada peraturan Bank Indonesia tentang sistem penilaian tingkat kesehatan bank adalah sebagai berikut :

Tabel 4. Standar Ukuran Rasio ROA

\begin{tabular}{|c|c|c|c|c|c|}
\hline \multirow{2}{*}{ Rasio Keuangan } & \multicolumn{5}{|c|}{ Standar Bank Indonesia } \\
\cline { 2 - 6 } & Sangat Baik & Baik & Cukup Baik & Kurang Baik & Tidak Baik \\
\hline ROA & $>1,5$ & $>1,25 \%$ & $0,5 \%<1,25 \%$ & $<0,5 \%$ & $\leq 0 \%$ \\
\hline
\end{tabular}

1. PT. Bank Rakyat Indonesia, Tbk meiliki rata-rata ROA sebesar 3,84\%, perolehan ROA dalam kondisi sangat baik ini berbanding lurus dengan rasio LDR, CAR, dan NPL yang masing-masing sebesar 77,54\%, 15,99\%, dan 2,30\%. Sehingga bank milik pemerintah yang menempati posisi kinerja terbaik dari sisi ROA adalah PT. Bank Rakyat Indonesia, Tbk.

2. PT. Bank Mandiri, Tbk memiliki nilai rata-rata ROA sebesar 2,94\% dengan predikat ROA dalam kondisi sangat baik. Namun hal ini berbanding lurus jika dilihat dari sisi LDR, CAR, dan NPL yang masing-masing sebesar 76,28\%, 15,65\% dan 0,70\%. PT. Bank Mandiri, Tbk mampu memperoleh ROA yang tinggi dikarenakan memiliki tingkat penyaluran kredit dan struktur modal yang baik, serta mampu menekan angka rasio kredit bermasalah yang cukup kecil.

3. PT. Bank Negara Indonesia, Tbk juga memiliki tingkat ROA yang sangat baik dengan rata-rata $2,28 \%$. Hal ini juga berbanding lurus dengan angka rasio LDR, CAR, dan NPL yang masing-masing sebesar 74,68\%, 16,39\% dan 0,90. PT. Bank Negara Indonesia, Tbk mampu memperoleh ROA yang tinggi dikarenakan memiliki tingkat penyaluran kredit dan struktur modal yang baik, serta mampu menekan angka rasio kredit bermasalah yang cukup kecil.

4. PT. Bank Tabungan Negara, Tbk memiliki rata-rata ROA sebesar 1,52\%. Perolehan ROA berbanding terbalik dengan angka rasio LDR dan CAR yang masing-masing sebesar 102,57\% dan 16,82\%. Secara kasat mata, perolehan rasio ROA yang berbanding terbalik dengan LDR dan CAR ini disebabkan tingginya angka rasio NPL yang mencapai 3,60\%. Meskipun hal ini berbanding terbalik, tetapi masih menempatkan PT. Bank Tabungan Negara, Tbk dalam kondisi ROA dengan predikat sangat baik. Perolehan laba yang cukup tinggi tentunya tidak lepas dari stabilnya kondisi perekonomian global, sehingga menyebabkan dapat beroperasional dengan baik. Perolehan laba yang cukup tinggi ini pula tentunya depengaruhi oleh beberapa faktor yang salah satunya adalah struktur modal yang memadai, tingkat penyaluran kredit, dan kecil nya angka kredit bermasalah. 
Pengaruh LDR, CAR, dan NPL Terhadap ROA Bank Milik Pemerintah Indonesia (BNI, BRI, BTN, Bank Mandiri) Tahun 2008-2015.

\section{Hasil uji regresi linear berganda}

Hasil uji regresi linear berganda dapat ditunjukkan pada tabel 1 sebagai berikut :

Tabel 5. Hasil Uji Regresi Linear Berganda

\begin{tabular}{crrrr}
\hline \hline Variable & Coefficient & Std. Error & t-Statistic & Prob. \\
\hline \hline C & 1.145402 & 1.144587 & 1.000712 & 0.3266 \\
LDR & 0.023074 & 0.007423 & 3.108708 & 0.0046 \\
CAR & 0.004924 & 0.038950 & 0.126411 & 0.9004 \\
NPL & -0.291975 & 0.061341 & -4.595179 & 0.0001 \\
\hline \hline
\end{tabular}

Dari tabel 5 di atas, persamaan regresi linear berganda dapat dirumuskan sebagai berikut: $\mathrm{Y}=1,145+$ $0,023 \mathrm{X}_{1}+0,004 \mathrm{X}_{2}-0,281 \mathrm{X}_{3}$. Hasil uji regresi linear berganda menunjukan bahwa :

1. Persamaan regresi linear berganda memiliki nilai konstanta sebesar 1.145. Artinya, jika LDR, CAR dan NPL nilainya adalah 0, maka ROA nilainya adalah Rp. 1.145,- (dalam jutaan rupiah)

2. Koefisien regresi variabel LDR sebesar 0.023. Artinya, jika nilai CAR dan NPL tetap dan LDR mengalami kenaikan sebesar Rp. 1.00,- maka ROA akan mengalami peningkatan sebesar Rp. 0.023. Koefisien bernilai positif artinya terjadi hubungan positif antara LDR dengan ROA.

3. Koefisien regresi variabel CAR sebesar 0,004. Artinya, jika nilai LDR, NPL tetap dan CAR mengalami kenaikan Rp. 1.00,- maka ROA akan mengalami peningkatan sebesar Rp. 0.004. Koefisien bernilai positif artinya terjadi hubungan positif antara CAR dengan ROA.

4. Koefisien regresi variabel NPL sebesar -0,281. Artinya, jika nilai LDR, CAR tetap dan NPL mengalami kenaikan Rp. 1.00,- maka ROA akan mengalami penurunan sebesar Rp. 0.281. Koefisien bernilai negatif artinya terjadi hubungan negatif antara NPL dengan ROA.

\section{Hasil Uji t (Parsial)}

Hasil uji t dapat dilihat pada tabel 6 sebagai berikut:

Tabel 6. Hasil Uji t (Parsial)

\begin{tabular}{crrrr}
\hline \hline Variable & Coefficient & Sto. Eror & t-Statistic & Prob. \\
\hline \hline L & 1.145402 & 1.144587 & 1.000712 & 0.3266 \\
CAR & 0.023074 & 0.007423 & 3.108708 & 0.0046 \\
NAP & 0.004924 & 0.038950 & 0.126411 & 0.9004 \\
\hline \hline
\end{tabular}

Pengambilan keputusan pada uji t adalah dengan menggunakan tingkat probabilitas sebesar 0,05 atau $5 \%$. Jika nilai probabilitas $<0,05$ maka terdapat pengaruh yang signifikan antara variabel independen terhadap variabel dependen. Selain menggunakan tingkat probabilitas, pengambilan keputusan juga menggunakan perbandingan antara nilai $t_{\text {hitung }}$ dan $t_{\text {tabel. }}$. Jika nilai $t_{\text {hitung }}>t_{\text {tabel, }}$ artinya terdapat pengaruh yang signifikan antara variabel independen terhadap variabel dependen. Sebaliknya jika nilai $t_{h i t u n g}<t_{\text {tabel, }}$ maka tidak terdapat pengaruh yang signifikan antara variabel independen terhadap variabel dependen. Hasil uji t pada tabel 2 dapat dijelaskan sebagai berikut :

1. LDR memiliki nilai thitung 3,108 > 1,693 tabel dengan tingkat signifikansi sebesar 0,0046 atau 0,46\%. Dengan demikian LDR berpengaruh positif dan signifikan terhadap ROA. Maka, hipotesis $\mathrm{H}_{1}$ yang menyatakan bahwa LDR berpengaruh positif dan signifikan terhadap ROA dapat diterima.

2. CAR memiliki nilai thitung 0,126 <1,693 tabel dengan tingkat signifikansi sebesar 0,9004 atau 90,4\%. Dengan demikian CAR mempunyai pengaruh yang positif dan tidak signifikan terhadap ROA. Maka, hipotesis $\mathrm{H}_{2}$ yang menyatakan bahwa CAR berpengaruh positif dan signifikan terhadap ROA ditolak.

3. NPL memiliki nilai thitung $-4,595<1,693$ tabel dengan tingkat signifikansi sebesar 0.0001 atau $0,01 \%$. Dengan demikian NPL mempunyai pengaruh yang negatif dan signifikan terhadap ROA. Maka, hipotesis $\mathrm{H}_{3}$ yang menyatakan bahwa NPL berpengaruh negatif dan signifikan terhadap ROA dapat diterima.

\section{Hasil Uji F (Simultan)}

Hasil uji F dapat dilihat pada tabel berikut :

Tabel 7. Hasil Uji F (Simultan) 
Effects Specification

\begin{tabular}{|c|c|c|c|}
\hline \multicolumn{4}{|c|}{ Cross-section fiked (dummy variables) } \\
\hline R-squared & 0.963750 & wean dependent var & 2.607500 \\
\hline Adjusted R-squared & 0.831050 & S.D. dependent var & 0.993755 \\
\hline S.E. of regression & 0.408468 & Akaike info criterion & 1.237835 \\
\hline Surn squared resid & 4.171158 & Schwarz criterion & 1.559465 \\
\hline Log likelihogd & -12.80536 & Hannan-Quinn criter. & 1.344115 \\
\hline F-statistic & 26.41437 & Durbin-Watson stat & 1.121162 \\
\hline Frob(F-statistic) & 0.000000 & & \\
\hline
\end{tabular}

Berdasarkan hasil uji F pada tabel 7 menunjukan hasil bahwa nilai Fhitung $26.414>2.93 \mathrm{Ftabel}_{\text {dengan }}$ tingkat signifikansi sebesar 0.000 atau $0,0 \%$ berada dibawah 0,05 atau 5\%. Dengan demikian LDR, CAR dan NPL secara simultan mempunyai pengaruh yang positif dan signifikan terhadap ROA. Maka, hipotesis $\mathrm{H}_{1}$ yang menyatakan bahwa LDR, CAR dan NPL berpengaruh positif dan signifikan terhadap ROA dapat diterima.

\section{Hasil Uji Koefisien Determinasi $\left(\mathbf{R}^{2}\right)$}

Uji koefisien determinasi digunakan untuk mengukur seberapa jauh kemampuan model dalam menjelaskan variasi variabel independen terhadap variabel dependen. Hasil koefisien determinasi $\left(R^{2}\right)$ pada tabel 7 di atas memiliki nilai 0,863 atau 86,3\% sedangkan 13,7\% dipengaruhi oleh variabel lain yang tidak diteliti.

\section{KESIMPULAN}

1. Hasil perhitungan perbandingan rasio kinerja keuangan dari sisi LDR secara rata-rata periode tahun 2008-2015, PT. Bank Negara Indonesia, Tbk memiliki kondisi LDR dengan predikat sangat baik, PT. Bank Mandiri, Tbk dan PT. Bank Rakyat Indonesia, Tbk memiliki kondisi LDR dengan predikat baik, sedangkan PT. Bank Tabungan Negara, Tbk memiliki kondisi LDR dengan predikat kurang baik. Hasil perhitungan dengan menggunakan uji secara parsial (uji t) menunjukkan rasio LDR bank milik pemerintah periode tahun 2008-2015 berpengaruh positif dan signifikan terhadap ROA dengan nilai thitung 3,108 > ttabel 1,693 dengan tingkat signifikan 0,0046 atau 0,46\%. Tingginya angka rasio LDR PT. Bank Tabungan Negara, Tbk salah satunya disebabkan oleh tingginya angka Kredit Perumahan Rakyat (KPR) yang secara rata-rata menggunakan jasa PT. Bank Tabungan Negara, Tbk.

2. Hasil perhitungan perbandingan rasio kinerja keuangan dari sisi CAR periode tahun 2008-2015, ke empat bank milik pemerintah memenuhi rasio kecukupan modal dengan predikat sangat baik, PT. Bank Tabungan Negara, Tbk sebesar 16,82\%, PT. Bank Negara Indonesia, Tbk sebesar 16,39\%, PT. Bank Rakyat Indonesia, Tbk 15,99\%, dan PT. Bank Mandiri, Tbk sebesar 15,65\%. Hasil perhitungan dengan menggunakan uji secara parsial (uji t) menunjukkan rasio CAR bank milik pemerintah periode tahun 2008-2015 berpengaruh positif dan tidak signifikan terhadap ROA dengan nilai thitung $0,126<$ $t_{\text {tabel }}$ 1,693 dengan tingkat signifikan 0,9004 atau 90,4\%. Rasio permodalan bank milik pemerintah berada dalam kondisi yang sangat baik, hal ini tentunya didukung oleh komitmen manajemen bank dalam memperhatikan struktur modal. Struktur modal yang kuat akan mampu membuat bank dapat beroperasional dengan baik.

3. Hasil perhitungan perbandingan rasio kinerja keuangan dari sisi NPL secara rata-rata periode tahun 2008-2015, pengelolaan kredit bermasalah dengan urutan PT. Bank Mandiri, Tbk sebesar 0,70\%, PT. Bank Negara Indonesia, Tbk 0,90\%, PT. Bank Rakyat Indonesia, Tbk sebesar 2,30\%, PT. Bank Tabungan Negara, Tbk sebesar 3,60\%. Secara predikat PT. Bank Mandiri, Tbk menempati posisi terbaik dalam hal pengelolaan kredit bermasalah. Hasil perhitungan dengan menggunakan uji secara parsial (uji t) menunjukkan rasio NPL bank milik pemerintah periode tahun 2008-2015 berpengaruh negatif dan tidak signifikan terhadap ROA dengan nilai thitung $-4,594<t_{\text {tabel }}$ 1,693 dengan tingkat signifikan 0,0001 atau 0,01\%. Manajemen bank milik pemerintah dirasa mampu menekan angka kredit bermasalah dibawah 5\% yang ditetapkan oleh Bank Indonesia. Berhasilnya manajemen bank dalam menekan angka kredit bermasalah tentunya didukung oleh stabilnya perekonomian dalam negeri, sehingga membuat konsumen dapat melakukanya kewajibannya sesuai pada waktu yang telah ditentukan.

4. Hasil perhitungan perbandingan rasio kinerja keuangan dari sisi ROA secara rata-rata periode tahun 2008-2015, PT. Bank Rakyat Indonesia, Tbk menempati posisi kinerja terbaik dengan ROA sebesar 3,84\%, PT. Bank Mandiri, Tbk sebesar 2,94\%, PT. Bank Negara Indonesia, Tbk sebesar 2,28\%, dan PT. Bank Tabungan Negara, Tbk memperoleh ROA paling rendah, yaitu sebesar 1,52\%. Hasil perhitungan 
dengan menggunakan uji secara simultan (uji F) menunjukkan rasio LDR, CAR, dan NPL bank milik pemerintah periode tahun 2008-2015 berpengaruh positif dan signifikan terhadap ROA dengan nilai $F_{\text {hitung }} 26,414>t_{\text {tabel }} 2,93$ dengan tingkat signifikan 0,000 atau 0,0\%. Perolehan laba yang cukup tinggi ini tentunya disebabkan oleh beberapa faktor, diantaranya adalah kuatnya struktur modal, bagusnya kualitas kredit, serta rendahnya angka kredit bermasalah.

5. Hasil pengujian koefisien determinasi $\left(\mathrm{R}^{2}\right)$ menunjukkan hasil bahwa variabel independen $L D R, C A R$, dan NPL dapat menjelaskan pengaruhnya terhada variabel dependen ROA, yaitu sebesar 0,863 atau 86,3\% sedangkan 13,7\% dipengaruhi oleh variabel lain yang tidak diteliti.

\section{SARAN}

1. Bank milik pemerintah (BNI, BRI, BTN, Bank Mandiri) harus memperhatikan sisi rasio LDR agar tidak melampaui batas maksimum yang ditetapkan oleh Bank Indonesia, terutama untuk PT. Bank Tabungan Negara, Tbk karena rasio LDR sudah dalam kondisi yang kurang baik dan dapat menimbulkan resiko terhadap bisnis perbankan.

2. Bank milik pemerintah (BNI, BRI, BTN, Bank Mandiri) harus memperkuat sisi struktur permodalan dari sisi rasio CAR, karena rasio CAR secara rata-rata periode tahun 2008 sampai tahun 2015 masih berada dibawah $20 \%$.

3. Bank milik pemerintah (BNI, BRI, BTN, Bank Mandiri) harus mengelola kredit bermasalah dari sisi rasio NPL agar tidak melampaui angka 5\% supaya tidak menimbulkan kredit yang beresiko tinggi, terutama dalam melakukan proses analisis pengajuan kredit agar tetap memperhatikan prinsip $5 \mathrm{C}$ (Character, Capacity, Capital, Collateral, Condition of Economy), teutama untuk PT. Bank Tabungan Negara, Tbk.

\section{DAFTAR PUSTAKA}

Dendawijaya, Lukman. 2008. Manajemen Perbankan. Jakarta : Ghalia Indonesia

Darminto, Dwi Prastowo. 2011. Analisis Laporan Keuangan, Konsep dan Aplikasi. Jakarta : UPP STIM YKPN. Fahmi, Irham. 2012. Analisis Kinerja Keuangan. Bandung : Alfabeta.

2014. Pengantar Perbankan Teori dan Aplikasi. Bandung : Alfabeta.

Hery. 2016. Analisis Laporan Keuangan. Jakarta : Bumi Aksara.

Kasiram, Mohammad. 2008. Metode Penelitian Kualitatif-Kuantitatif. Malang : UIN Malang Press.

Kasmir. 2008. Bank dan Lembaga Keuangan Lainnya, Edisi Keenam. Jakarta : PT. Raja Grafindo Persada.

------2009. Bank dan Lembaga Keuangan Lainnya. Jakarta : Rajawali Pers.

-------2010. Dasar-Dasar Perbankan. Jakarta : PT. Raja Grafindo Persada.

---.-2012. Analisis Laporan Keuangan. Jakarta : PT. Raja Grafindo Persada.

Otoritas Jasa Keuangan. 2016. Booklet Perbankan Indonesia. Jakarta : Departemen Perizinan dan Informasi Perbankan.

Pandia, Frianto. 2012. Manajemen Dana dan Kesehatan Bank. Jakarta : Rineka Cipta.

Riadi, Edi. 2016. Statistika Penelitian, Analisis Manual dan IBM SPSS. Yogyakarta : Andi.

Suwarni, S., Susena, K. C., \& Gusti, W. Analisis kinerja keuangan PT. Bank Sinarmas tbk, unit usaha syariah. Taswan. 2010. Manajemen Perbankan, Edisi Kedua. Yogyakarta : UPP STIM YKPN

Tika, Moh Pabundu. 2006. Budaya Organisasi dan Peningkatan Kinerja Perusahaan. Jakarta : PT. Raja Grafindo Persada.

Undang-Undang Republik Indonesia Nomor 10 tahun 1998 tentang Perubahan Undang-Undang Nomor 7 tahun 1992 tentang Perbankan. Jakarta : Bank Indonesia.

Wijaya, Toni. 2011. Cepat Menguasai SPSS 19. Yogyakarta : Cahaya Atma.

www.idx.go.id 